\title{
THE EFFECTIVENESS OF THE USE OF A MODEL OF LEARNING SNOWBALL THROWING TOWARDS THE MATHEMATICS LEARNING OUTCOME ON THE STUDENTS
}

\author{
Riri Ratna Anggraini ${ }^{a}$, Uus Kusdinar ${ }^{b}$ \\ Mathematics Education Study Program, University of Ahmad Dahlan \\ Jalan Ringroad Selatan, Tamanan, Banguntapan, Bantul, Yogyakarta \\ aririratnaa@gmail.com, buus.kusdinar@pmat.uad.ac.id
}

\begin{abstract}
The research was done because the learning model which is usually applied in SMP Negeri 2 Girimulyo still tends to be centered on teachers and makes students passive in the learning process. Snowball Throwing is one of many kinds of teaching and learning strategy which provides opportunities to the students to be actively involved in the class activity. The objectives of this research are (1) to know the diversities in the math learning outcome of the eighth-grade students which are taught using the expository learning strategy in the second semester of SMP Negeri 2 Girimulyo in the academic year of 2015/2016, (2) to know the effectiveness of the cooperative learning strategy type Snowball Throwing towards the expository learning strategy to the eighth-grade students in the second semester of SMP Negeri 2 Girimulyo in the academic year of 2015/2016. This research used the quantitative research method. The population of the research was the eighth-grade students in the second semester of SMP Negeri 2 Girimulyo in the academic year of 2015/2016. To obtain the sample, this research used the random sampling technique. As the sample, this research managed the VIII B class as the Experiment Class and VIIIA as the Controlled Class. A test was applied for the data collecting technique of this research. To calculate the instrument validity and reliability, this research used the product-moment correlation and the Alpha formula. The data analyzing the technique of this research are the t-test, the normality test used the Chi-Quadrate formula, and homogeneity test used the Bartlett test. Based on the research findings at the 5\% significance level and a degree of freedom of 61 , thus the accumulations are (1) $t_{\text {table }}=1,6702$ and $t_{c a l}=6,4198$. It collected $t_{\text {cal }}>t_{\text {table }}$ so $H_{0}$ is rejected. Henceforward, there are diversities in the math learning marks of the students who were taught using the cooperative learning strategy type Snowball Throwing towards those which were taught using the expository learning strategy. (2) $t_{\text {table }}=1,6702$ and $t_{c a l}=6,4198$, collected $t_{c a l}>t_{\text {table }}$ so $H_{0}$ is rejected. To put it briefly, the cooperative learning strategy type Snowball Throwing is more effective than the expository learning strategy towards math learning marks.
\end{abstract}

Keywords: the effectiveness, Snowball Throwing, learning outcome

\section{INTRODUCTION}

Education is one of the important needs for the progress of a nation and cannot be separated from human life. Because indicators of a nation's progress can be seen from the quality of its education. The quality of good education will certainly produce quality Human Resources (HR) as well. Mathematics can be said to be the mother or queen of science, meaning that many other sciences whose findings and development depend on mathematics. Directly or indirectly, many aspects and human activities use mathematical concepts and calculations. Mathematics is one of the abstract lessons because mathematical objects are in the form of mind-objects, to understand them requires thinking skills. Besides, it also requires perseverance and enthusiasm from students to learn it.

The problem now is how to find the best way to convey the various concepts taught so that students can use and remember the concept and how creative teachers always use a variety of learning models to increase students' interest in participating in the learning process. Based on the results of observations and interviews with a math teacher on November 2, 2015, at SMP N 2 Girimulyo, Kulonprogo Regency, class VIII teaching and learning activities in the classroom, the teacher still uses the expository learning model wherein the learning process a teacher to students inside the class by 
speaking at the beginning of the lesson, explaining the material and examples of questions with questions and answers. During the learning process, communication occurs in one direction, from teacher to student so that student activities are more likely to be busy with their activities, students are also less active in learning, students only listen to explanations from the teacher, record important things from the examples given by the teacher and discuss questions together. The lack of student activity results in students being unable to express ideas, ideas and concepts optimally. The teacher still considers that the ability of students to master subject matter is more important than developing thinking skills. Therefore, researchers want to develop students' thinking skills by applying learning models that can be fun and can personally attract students to think. Based on the Semester Middle Test (SMT) value data obtained from the eighthgrade math teacher of SMP N 2 Girimulyo in Kulonprogo Regency, it was found that the number of students who were less than the Minimum Completion Criteria (CCM) was 82 students or more than $50 \%$ of 94 students had not achieved grades CCM. This shows that students' mathematics learning outcomes are still low.

One learning model that can develop students' thinking skills is by applying the Snowball Throwing type cooperative learning model. With the use of the Snowball Throwing learning model, it is expected that in a couple or small groups of students with high abilities can help other students who have low abilities through joint discussions so that later it will be able to improve mathematics learning outcomes better. Snowball Throwing learning strategy or also known as Snowball Flight is learning that was first adopted from a physical game where a snowflake was thrown to hit other people. In the context of learning, Snowball Throwing is applied by throwing a lump of paper to designate the required answer from the teacher. This strategy is used to provide the concept of understanding material that is difficult for students and can also be used to determine the extent of students' knowledge and abilities in the material. (Huda, 2015, p. 226). Also, (Hasan Fauzi Maufur in Fathurrohman, 2015, p. 61) states that Snowball Throwing learning model trains students to be more responsive to receiving messages from others and conveying the message to friends in one group. Question throws don't use sticks like the Talking Stick learning model but use paper containing questions that are squeezed into a paper ball and then thrown at other students, students who get a paper ball and then open and answer the question. In Snowball Throwing learning students are formed in several groups represented by the group leader to get assignments from the teacher, then each student makes a question that is shaped like a ball (question paper) and then thrown to other students and each student answers questions from the ball obtained. In line with this, Afandi's (2011) study showed that there was an increase in mathematics learning outcomes using the Snowball Throwing learning model from the first cycle to the second cycle. Besides, the research of Isnaeni (2015) shows that learning mathematics using the Snowball Throwing type cooperative learning model can improve the ability to solve math problems. The linkage of the above research with this research is that both use the Snowball Throwing type cooperative learning model. But the effectiveness of the Snowball Throwing cooperative learning model with expository learning models on student learning outcomes does not yet exist.

\section{METHODS}

The type of research is a type of experimental research. This study used two classes, the experimental class I was conducted learning with the Snowball Throwing type cooperative learning model, while the experimental class II was conducted using the expository learning model. In this study, the posttest used was the same for Experiment I class and Experiment II class. The design of this study is illustrated in Table 1.

Table 1. Research design

\begin{tabular}{|c|c|c|c|}
\hline Class & Initial ability & Treatment & Posttest \\
\hline B & $O_{1}$ & $X_{1}$ & $Y_{1}$ \\
\hline $\mathbf{A}$ & $\mathrm{O}_{2}$ & $X_{2}$ & $Y_{2}$ \\
\hline
\end{tabular}


Information:

$O_{1} \quad$ : Experimental ability early class I

$\mathrm{O}_{2} \quad$ : Experimental ability early class II

$X_{1} \quad$ : The treatment uses the Snowball Throwing type cooperative learning model.

$X_{2} \quad$ : The treatment uses the expository learning model.

$Y_{1} \quad$ : Posttest results of the Experiment class I

$Y_{2} \quad$ : Posttest results of the Experiment class II

This research was conducted at SMP N 2 Girimulyo in Kulonprogo Regency. The time used for data collection in this study is the even semester 2015/2016 academic year. The total number of eighthgrade students of SMPN 2 Girimulyo District Kulonprogo of 2015/2016 academic year is 94 students consisting of 3 classes, namely class VIII A, VIII B, VIII C. In this study the sample was done by random sampling, selected class VIII B as experimental class I and class VIII A as experimental class II. Data collection techniques used are documentation methods and test methods. Documentation used in the form of midterm test scores for grade VIII students of SMPN 2 Girimulyo to find out data about the value of students' initial abilities before the experiment was conducted. While the test is used to obtain the value of mathematics learning outcomes of students in class VIII SMPN 2 Girimulyo in the class taught by the Snowball Throwing type cooperative learning model and the class taught using the expository learning model.

The instrument used is a test of mathematics learning outcomes in the form of a description test. The score obtained is the ability of students in the learning outcomes of mathematics. This test is prepared by researchers in consultation with the supervisor and subject matter teacher concerned. The problem related to the subject is Polyhedron. Before use, the device is tested first to determine the questions to be chosen. After the test instruments were arranged, then tested on the instrument trial class, namely class VIII C. After the test questions were tested, the test items were analyzed by validity test using the productmoment correlation formula (Arikunto, 2012, p.87) and reliability testing use alpha formulas (Arikunto, 2012, p.122). The analysis prerequisite test used the normal test with the Chi-Square test (Khasanah, 2014, p.8) and homogeneity test with a Bartlett test (Sudjana, 2001, p.263). Hypothesis testing is used ttest (Sudjana, 2001, p.239) two parties or one party.

\section{RESULTS AND DISCUSSION}

Based on the research that has been carried out obtained data in the form of initial abilities and student learning outcomes.

\section{Initial ability}

\section{a. Normal Ability Test}

The summary results of the normal ability normality test can be seen in Table 2 .

Table 2. Summary of Initial Ability Normality Test Results

\begin{tabular}{lrc}
\hline Kelas & $\chi^{\mathbf{2}}$ count & $\chi^{\mathbf{2}}{ }_{\text {table }}$ \\
\hline Experiment I & 0,5085 & 5,9915 \\
Experiment II & 4,2944 & 7,8147 \\
\hline
\end{tabular}

From the normality test at a significant level of $5 \%$ and the degree of freedom $=2$, it can be seen that $\chi_{\text {count }}^{2}=0,5085$ and $\chi_{\text {table }}^{2}=5,9915$, so $\chi_{\text {count }}^{2}<\chi_{\text {table }}^{2}$ It means that in the experimental class I have initial ability data that are normally distributed. While the normality test at a significant level of $5 \%$ and the degree of freedom $=3$, it can be seen that $\chi_{\text {count }}^{2}=$ 4,2944 and $\chi_{\text {table }}^{2}=7,8147$, so $\chi_{\text {count }}^{2}<\chi_{\text {table }}^{2}$ which means the experimental class II has initial ability data that are normally distributed. 


\section{b. Homogeneity Test of Early Capabilities}

The summary results of the initial homogeneity test can be seen in Table 3 .

Table 3. Summary of Initial Ability Homogeneity Test Results

\begin{tabular}{cc}
\hline$\chi_{\text {count }}^{2}$ & $\chi_{\text {table }}^{2}$ \\
\hline 0,8860 & 3,8415 \\
\hline
\end{tabular}

From the homogeneity test at a significant level of 5\% and the degree of freedom $=1$, it can be seen that $\chi_{\text {count }}^{2}=0,8860$ and $\chi_{\text {table }}^{2}=3,841$, so $\chi_{\text {count }}^{2}<\chi_{\text {table }}^{2}$ which means both classes have the same variance (homogeneous).

c. Test the First Hypothesis of the Initial Capability Value

The summary of the results of the hypothesis test the similarity of the initial capabilities can be seen in Table 4.

Table 4. Summary of Results of the First Hypothesis Test of Initial Capability Value

\begin{tabular}{cc}
\hline $\boldsymbol{t}_{\text {count }}$ & $\boldsymbol{t}_{\text {table }}$ \\
\hline $\mathbf{0 , 1 2 0 0}$ & 1,6702 \\
\hline
\end{tabular}

From the hypothesis test of similarity at a significant level of 5\% and the degree of freedom $=$ 61 , it can be seen that $t_{\text {count }}=0,1200$ and $t_{\text {table }}=1,6702$, so $t_{\text {count }}<t_{\text {table }}$ This means there is no difference between the initial ability of students using the Snowball Throwing type cooperative learning model and the students' initial ability to use the expository learning model in class VIII SMPN 2 Girimulyo in Kulonprogo District even semester 2015/2016 academic year.

\section{Mathematics Learning Outcomes}

a. Normality Test of Learning Outcomes

The summary test for normality of learning outcomes can be seen in Table 5 .

Table 5. Summary of Normality Tests for Learning Outcomes

\begin{tabular}{crc}
\hline Class & $\chi_{\text {count }}^{2}$ & $\chi^{2}{ }_{\text {table }}$ \\
\hline Experiment I & 1,9434 & 5,9915 \\
Experiment II & 2,9485 & 5,9915 \\
\hline
\end{tabular}

From the normality test at a significant level of $5 \%$ and degrees of freedom $=2$, it can be seen that $\chi_{\text {count }}^{2}=1,9434$ and $\chi_{\text {table }}^{2}=5,9915$, so $\chi_{\text {count }}^{2}<\chi_{\text {table }}^{2}$ which means that the experimental class I have learning outcomes data that are normally distributed. While the normality test at a significant level of $5 \%$ and degrees of freedom $=2$, it can be seen that $\chi_{\text {count }}^{2}=2,9485$ and $\chi_{\text {table }}^{2}=5,9915$, so $\chi_{\text {count }}^{2}<\chi_{\text {table }}^{2}$ which means the experimental class II has learning outcomes data that are normally distributed.

\section{b. Homogeneity Test of Learning Outcomes}

The summary test of homogeneity of learning outcomes can be seen in Table 6 .

Table 6. Summary of Homogeneity Test of Learning Outcomes

\begin{tabular}{cc}
\hline$\chi_{\text {count }}$ & $\chi_{\text {table }}$ \\
\hline 0,1649 & 3,8415 \\
\hline
\end{tabular}

From the homogeneity test at a significant level of $5 \%$ and the degree of freedom $=1$, it can be seen that $\chi_{\text {count }}^{2}=0,1649$ and $\chi_{\text {table }}^{2}=3,8415$ so $\chi_{\text {count }}^{2}<\chi_{\text {table }}^{2}$ which means both classes have the same variance (homogeneous).

\section{c. Test the First Hypothesis}

The summary of the results of the first hypothesis test can be seen in Table 7 . 
Table 7. Summary of Test of the First Hypothesis

\begin{tabular}{cc}
$\boldsymbol{t}_{\text {count }}$ & $\boldsymbol{t}_{\text {table }}$ \\
\hline $\mathbf{6 , 4 1 9 8}$ & 1,6702 \\
\hline
\end{tabular}

From the first hypothesis test at a significant level of $5 \%$ and the degree of freedom $=61$, it can be seen that $t_{\text {count }}=6,4198$ and $t_{\text {table }}=1,6702$, so $t_{\text {count }}>t_{\text {table }}$ which means that there is a difference between the mathematics learning outcomes of students taught using the Snowball Throwing type cooperative learning model more effectively than the expository learning model on mathematics learning outcomes on the subject of polyhedron at class VIII even semester of SMPN 2 Girimulyo in Kulonprogo academic year 2015 / 2016.

\section{d. Test the Second Hypothesis}

After it was known that there was no difference between the mathematics learning outcomes of students in the experimental class I with the experimental class II, then the second hypothesis was tested, as can be seen in Table 8 .

Table 8. Summary of Tests for the Second Hypothesis

\begin{tabular}{cc}
$\boldsymbol{t}_{\text {count }}$ & $\boldsymbol{t}_{\text {table }}$ \\
\hline $\mathbf{6 , 4 1 9 8}$ & 1,6702 \\
\hline
\end{tabular}

From the second hypothesis test at a significant level of 5\% and the degree of freedom $=61$, it can be seen that $\boldsymbol{t}_{\text {count }}=6.4198$ and $\boldsymbol{t}_{\text {table }}=1.6702$, so $\boldsymbol{t}_{\text {count }}>\boldsymbol{t}_{\text {table }}$ which means the Snowball Throwing type cooperative learning model is more effective than the expository learning model for mathematics learning outcome on the subject of polyhedron in even semester of class VIII students.

\section{CONCLUSION}

Based on the results of research and discussion, conclusions can be drawn, namely:

1. There is a difference between the mathematics learning outcomes of students who are taught using the Snowball Throwing type cooperative learning model and students who are taught to use the expository learning model on the subject of Building Data Sides Space

2. Grade VIII students in the even semester of SMPN 2 Girimulyo Kulonprogo know the 2015/2016 teachings. This is indicated by the results of the two-party hypothesis test with a significant level of $5 \%$ and 61 degrees of freedom, obtained by the value $t_{\text {count }}=6.4198$ and $t_{\text {table }}=1.6702$. Where $t_{\text {count }}>t_{\text {table }}$ so that $\mathrm{H}_{0}$ is rejected and $\mathrm{H}_{1}$ is accepted.

3. The Snowball Throwing type cooperative learning model is more effective than the expository learning model on mathematics learning outcomes on the subject of Polyhedron in class VIII of the even semester of SMPN 2 Girimulyo in Kulonprogo academic year 2015/2016. This is indicated by the results of a one-party hypothesis test with a significant level of 5\% and 61 degrees of freedom, obtained by $t_{\text {count }}=6.4198$ and $t_{\text {table }}=1.6702$. Where $t_{\text {count }}>t_{\text {table }}$ so that $\mathrm{H}_{0}$ is rejected and $\mathrm{H}_{1}$ is accepted.

\section{SUGGESTION}

Based on the conclusions above, then some suggestions that can be revealed by researchers are as follows:

1. The use of the Snowball Throwing learning model can be used as one of the learning models in class because it requires students to think more. However, the teacher should be able to master the class and material while learning is in progress.

2. The research carried out is limited to the subject matter of polyhedron so that it is expected that other researchers can expand the problem, for example, it can be applied to other materials and even wider samples. 


\section{REFERENCES}

Afandi, E. T. N. 2011. "Upaya Meningkatkan Hasil Belajar Matematika dengan Menggunakan Model Pembelajaran Kooperatif Tipe Snowball Throwing pada siswa kelas VIII Semester Genap SMP Negeeri 1 Bawang Banjarnegara Tahun Ajaran 2010/2011". Skripsi. Universitas Ahmad Dahlan.

Arikunto, Suharsimi. 2012. Dasar-Dasar Evaluasi Pendidikan Edisi Kedua. Jakarta: Bumi Aksara. Fathurrohman, M. 2015. Model-Model Pembelajaran Inovatif. Yogyakarta: Ar-Ruzz Media. Huda, Miftahul. 2015. Model-Model Pengajaran dan Pembelajaran. Yogyakarta: Pustaka Pelajar.

Isnaeni, T. L. 2015. “Upaya Meningkatkan Kemampuan Menyelesaikan Soal Matematika Menggunakan Model Pembelajaran Kooperatif Tipe Snowball Throwing pada Kelas VII Semester Ganjil SMP Negeri 2 Sanden Kabupaten BantulTahun Ajaran 2014/2015". Skripsi. Universitas Ahmad Dahlan.

Khasanah, Uswatun. 2014. Analisis Regresi. Yogyakarta : MIPA UAD Press.

Sudjana. 2001. Metoda Statistika. Bandung : Tarsito 